\title{
EFFECT OF RAMS ON THE DURATION OF OESTROUS BEHAVIOUR IN EWES
}

\author{
I. G. FLETCHER* AND D. R. LINDSAY $\dagger$ \\ Department of Animal Husbandry, University of Sydney, Australia
}

(Received 7th July 1970)

\begin{abstract}
Summary. The effect of rams on the duration of oestrous behaviour was studied with oestrogen-treated spayed ewes. Different degrees of association between ewes and rams influenced the duration of oestrus in two ways.

First, the duration of oestrus measured by teasing ewes with active rams once every $4 \mathrm{hr}$ was shorter when ewes and rams remained together than when they were kept apart between observations. Continuous contact with rams appeared to limit the duration of oestrus by inhibiting the neural mechanism controlling the expression of oestrous behaviour.

Second, the duration of oestrus measured by teasing ewes individually every $4 \mathrm{hr}$ and keeping them with rams between observations was longer than that measured when ewes were kept in continuous uncontrolled association with rams. Regular teasing probably resulted in a longer duration of oestrus because it eliminated competition between ewes and rams and overcame the apparent unwillingness of rams to continue to mate with the same ewes for the full duration of their oestrus.

The incidence, time of onset, and duration of oestrous behaviour all responded linearly to increasing doses of oestrogen, but the slopes of these dose-response relationships were not affected by the different methods of measuring oestrous behaviour.
\end{abstract}

\section{INTRODUCTION}

Rams may influence the duration of oestrous behaviour in ewes. Parsons \& Hunter (1967) showed that ewes held in continuous association with rams remained in oestrus for a shorter period than ewes allowed only intermittent contact with rams, but the mechanisms by which rams modified the expression of oestrous behaviour have not been established. This paper reports a study of oestrous behaviour in ewes with particular reference to the effects of varying association between ewes and rams on the measured duration of oestrus.

\section{METHODS}

Two investigations were carried out in sequence with sixty-six Border Leicester

* Present address: Department of Agriculture, Turretfield Research Centre, Rosedale, South Australia 5350.

$\dagger$ Present address: Institute of Agriculture, University of Western Australia, Nedlands, Western Australia 6009. 
$\times$ Merino crossbred ewes. All ewes were ovariectomized and oestrous behaviour was induced synchronously in a manner similar to that described by Robinson \& Moore (1956). Six injections of progesterone, the first five of $20 \mathrm{mg}$ and the sixth of $10 \mathrm{mg}$, were administered at 2-day intervals, and a single injection of oestradiol benzoate (ODB) was administered $48 \mathrm{hr}$ after the last injection of progesterone. Both hormones were dissolved in peanut oil and injected intramuscularly. The advantages of controlled oestrus over normally-occurring oestrus for behavioural investigations have been discussed previously (Lindsay, 1966).

\section{Experiment 1}

The factorial design is shown in Table 1. All ewes were treated with progesterone, and injected with logarithmically-spaced doses of oestrogen (24.3, 38.0 or $59.2 \mu \mathrm{g}$ of ODB). Half of the ewes at each dose level of oestrogen were held indoors and teased with active rams every $4 \mathrm{hr}$, while the other half were run continuously with rams in the field. Observations were made on the incidence of oestrus, the interval between oestrogen injection and onset of oestrus, and the duration of oestrus.

TABLE 1

FACTORIAL DESIGN OF EXPERIMENT 1

\begin{tabular}{l|c|c|c}
\hline \multicolumn{1}{c|}{ Comparison } & Description & Factors & $n^{*}$ \\
\hline 1. Dose of oestrogen & $\begin{array}{c}24 \cdot 3 \text { versus } 38 \cdot 0 \\
\text { versus } 59 \cdot 2 \mu \mathrm{g} \text { ODB } \\
\text { 4-hourly teasing indoors } \\
\text { versus continuous associa- } \\
\text { tion between ewes and } \\
\text { rams in the field } \\
\text { oestrous behaviour }\end{array}$ & 22 & 33 \\
\hline
\end{tabular}

Number of ewes in each sub-class = eleven, total number $=$ sixty-six.

* Number of ewes contributing to the mean for each comparison.

Indoor observations were made in a large, well-lit shed fitted with pens approximately $2 \times 4 \mathrm{~m}$ in size. Ewes and rams were held in the shed from the time of oestrogen injection until the end of oestrus, but were put out to pasture for two or three periods between observations each day. Initially, a single ram was put into each pen holding approximately ten ewes for a period of $1 \mathrm{hr}$ in every 4 and ewes were removed as they were detected in oestrus. The onset of oestrus was taken to be mid-way between the previous observation and the one at which the ewes first mated. Once detected in oestrus, each ewe was teased every $4 \mathrm{hr}$ until she had failed to allow service for two successive observations. The end of oestrus was taken to be mid-way between the last observation at which the ewe allowed service and the subsequent one when she first failed to do so. About thirty Merino rams were used in rotation and changed frequently so that only actively working rams were with the ewes throughout each observation.

Outdoor observations were made in a field of $I \cdot 6$ ha. Four Merino rams fitted with harnesses and marking crayons were put with the ewes immediately after they were injected with oestrogen, and remained with them until the end 
of oestrus. Raddle colours on the ram harnesses were changed every $4 \mathrm{hr}$, using the colours blue, red and green in rotation. Every $12 \mathrm{hr}$, the ewes were held briefly in yards, and each 4-hr period during which they had mated was determined from the different raddle colours on their rumps. These raddle marks were removed by washing with a warm solution of strong detergent before the ewes were returned to the field. The time of onset of oestrus was taken to be the middle of the 4-hr period during which the ewe was first raddled by a ram. Similarly, the end of oestrus was taken to be the middle of the last 4-hr period during which the ewe mated.

\section{Experiment 2}

All ewes were treated with progesterone and injected with $24 \cdot 3 \mu \mathrm{g}$ of ODB. After oestrogen was injected, the ewes were first held indoors and teased with active rams for a period of $1 \mathrm{hr}$ in every 4 to determine the time of onset of oestrus. As ewes were detected in oestrus, they were allotted at random to three groups and durations of oestrus were measured by three different methods. These were:

Group 1: contact with a ram once every $4 \mathrm{hr}$. The ewes were held indoors and individually teased with rams once every $4 \mathrm{hr}$. Between observations, the ewes had visual but not physical contact with rams in adjacent pens.

Group 2: continuous association with rams indoors. The ewes were held indoors and individually teased with rams once every $4 \mathrm{hr}$ as in Group 1 . One ram remained with each pen of approximately ten ewes between observations.

Group 3: continuous association with rams in the field. The ewes were run continuously with four rams in a field of $1.6 \mathrm{ha}$. The rams were replaced with fresh animals every $4 \mathrm{hr}$ to ensure that the activity of the rams remained at a high level throughout the observations.

Durations of oestrous behaviour both indoors and in the field were determined in the manner already described.

\section{RESULTS}

\section{Experiment 1}

The main effects are shown in Table 2. The incidence and duration of oestrus increased linearly, and the interval between injection of oestrogen and onset of oestrus decreased linearly, with increasing dose of oestrogen. The method of observation affected neither the total number of ewes detected in oestrus nor the interval between injection of oestrogen and onset of oestrus. The duration of oestrus when ewes and rams were kept separate and teased only once in every $4 \mathrm{hr}$ was almost twice as long as the duration of oestrus when ewes and rams were held in continuous association in the field.

There were no significant interactions between dose of oestrogen and method of observation. This is apparent from the linear regressions of the three parameters of oestrous behaviour on log dose of oestrogen, presented in Text-fig. 1 . The method of observation influenced the measurement of oestrous behaviour equally at all doses of oestrogen, and did not significantly affect the slopes of the dose-response lines. 
TABLE 2

EFFECTS OF METHOD OF OBSERVATION ON THREE MEASURED GHARACTERISTICS OF OESTROUS BEHAVIOUR AT THREE DOSES OF OESTROGEN

\begin{tabular}{|c|c|c|c|}
\hline Main effects & $\begin{array}{l}\% \text { of ewes } \\
\text { detected } \\
\text { in oestrus }\end{array}$ & $\begin{array}{l}\text { Mean interval } \\
\text { between } O D B \\
\text { injection and } \\
\text { onset of oestrus } \\
\text { (hr) }\end{array}$ & $\begin{array}{c}\text { Mean duration } \\
\text { of oestrus } \\
(h r)\end{array}$ \\
\hline $\begin{array}{l}\text { 1. Dose of ODB }(\mathrm{n}=22) \\
24 \cdot 3 \mu \mathrm{g} \\
38 \cdot 0 \mu \mathrm{g} \\
59 \cdot 2 \mu \mathrm{g} \\
P \text { linear } \\
P \text { quadratic }\end{array}$ & $\begin{array}{l}77 \cdot 3 \\
85 \cdot 7 \\
100 \cdot 0 \\
<0.05 \\
\text { N.s. }\end{array}$ & $\begin{array}{l}23 \cdot 6 \\
19 \cdot 3 \\
16 \cdot 7 \\
<0.01 \\
\text { N.s. }\end{array}$ & $\begin{array}{l}21.9 \\
26.7 \\
40.3 \\
<0.001 \\
\text { N.s. }\end{array}$ \\
\hline $\begin{array}{l}\text { 2. Method of observation }(n=33) \\
\text { 4-hourly teasing indoors } \\
\text { Continuous association between } \\
\text { ewes and rams in the field } \\
P\end{array}$ & $\begin{array}{l}87 \cdot 5 \\
87 \cdot 9 \\
\text { N.s. }\end{array}$ & $\begin{array}{l}18 \cdot 7 \\
20 \cdot 5 \\
\text { N.s. }\end{array}$ & $\begin{array}{l}40 \cdot 1 \\
21 \cdot 2 \\
<0.001\end{array}$ \\
\hline
\end{tabular}

Note: there were no significant interactions.
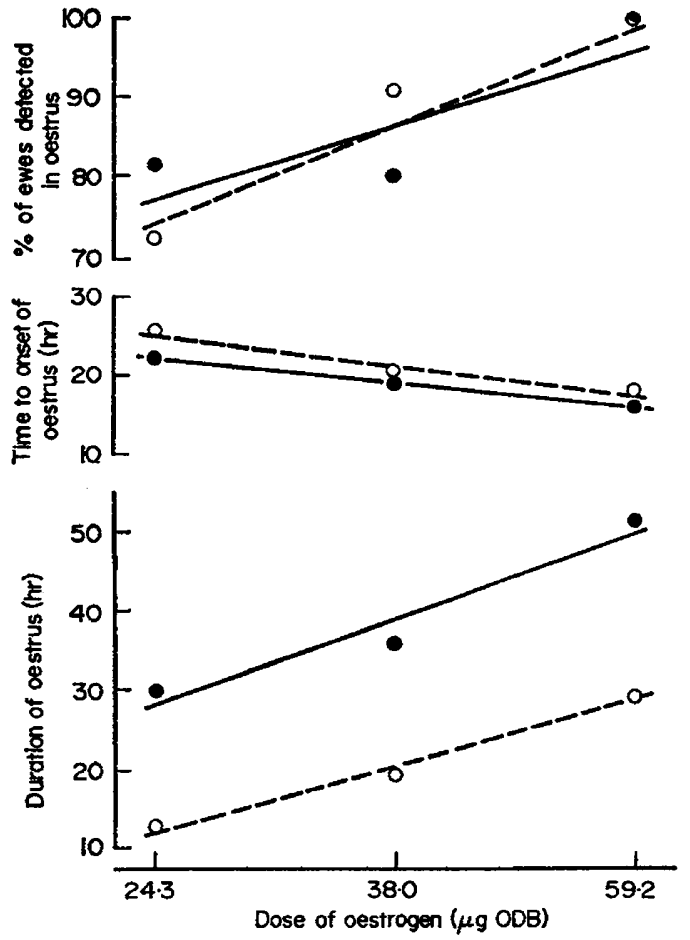

TEXT-Fio. 1. Linear responses of the incidence, time of onset, and duration of oestrous behaviour on log dose of oestrogen ( $\bullet$, measured from 4-hourly teasing indoors; 0 , measured from continuous ewe-ram association in the field). 
Experiment 2

Fifty-eight ewes showed oestrous behaviour after oestrogen injection, and the results are summarized in Table 3 . Ewes which were allowed contact with a ram only once in every $4 \mathrm{hr}$ were in oestrus for longer than those which were kept with rams continuously. Further, when ewes were kept with rams continuously, durations of oestrus measured by 4-hourly teasing indoors were longer than those measured from uncontrolled ewe-ram association in the field.

TABLE 3

EFFEGTS OF PERIODIC AND GONTINUOUS ASSOCIATION WITH RAMS ON THE DURATION OF OESTROUS BEHAVIOUR

\begin{tabular}{l|c}
\hline \multicolumn{1}{c|}{ Association with rams } & $\begin{array}{c}\text { Mean duration of } \\
\text { oestrous }(h r \pm S . E .)\end{array}$ \\
\hline 1. Contact with a ram once every $4 \mathrm{hr}(\mathrm{n}=19)$ & $34 \cdot 5 \pm 1 \cdot 79$ \\
2. Continuous association with rams indoors $(\mathrm{n}=19)$ & $26.5 \pm 1 \cdot 84$ \\
3. Continuous association with rams in the field $(\mathrm{n}=20)$ & $20 \cdot 0 \pm 2 \cdot 03$ \\
\hline
\end{tabular}

Differences between treatment means: 1 versus $2+3 P<0.001$. 2 versus $3 P<0.05$.

\section{DISCUSSION}

The duration of oestrous behaviour measured by keeping ewes and rams separate except for brief periods of observation every $4 \mathrm{hr}$ was almost twice as long as that measured from the continuous association of ewes and rams in the field. This confirms for spayed ewes the evidence of Parsons \& Hunter (1967) that oestrous behaviour in entire ewes was longer with intermittent than with continuous association between ewes and rams. Further, it defines more clearly the nature of this effect. Oestrous behaviour results from the action of oestrogen on specific areas of the hypothalamus (Donovan \& Harris, 1966; Lisk, 1966), and duration of oestrus increases with increasing level of oestrogen (Fletcher \& Lindsay, 1971). Association with rams could influence the duration of oestrus in entire ewes either through a direct effect on the neural mechanism controlling oestrous behaviour, or through an indirect effect on the elaboration of oestrogen from the ovaries. In this experiment, variation in ovarian oestrogen production was eliminated by using spayed ewes and injecting controlled doses of oestrogen. The effect of continuous association between ewes and rams in reducing the duration of oestrus, therefore, is considered to result from a direct psychic inhibition of the neural mechanism which controls the expression of oestrous behaviour.

This psychic inhibition was confirmed in the second experiment, where the duration of oestrus measured by teasing ewes every $4 \mathrm{hr}$ was shorter when ewes and rams remained together than when they were separated between observations. However, even when ewes remained in continuous association with rams, those held in uncontrolled association in the field still showed a shorter duration of oestrus than those held indoors and teased every $4 \mathrm{hr}$. Thus, continuous contact with rams was not the only factor contributing to the short duration of oestrus recorded in the field. Social relationships between ewes and rams also appear to be involved. 
The measurement of duration of oestrus under conditions of uncontrolled association between ewes and rams assumes that ewes mate with a ram immediately they come into oestrus, and that they continue to do so until the end of oestrus, though these assumptions may be unreliable. For example, oestrous ewes compete for the attention of a ram (Hulet, Ercanbrack, Price, Blackwell \& Wilson, 1962), and it is unlikely, therefore, that all ewes are noticed and mated by a ram immediately they come into oestrus. Observations by Pepelko \& Clegg (1965) that rams mate less frequently when they remain with the same ewes than when the ewes are changed, and by Lindsay (1966) that individual rams show an inability or unwillingness to mate with all of several ewes in oestrus at the one time, indicate that rams in continuous contact with the same ewes may not continue to mate with them for the full period during which they are receptive. It was not possible to distinguish between the effects of these different social factors, but they would all be eliminated by teasing ewes individually with active rams at regular intervals, and therefore all probably contributed to the short duration of oestrus measured from uncontrolled association between ewes and rams in the field.

Whether intermittent ewe-ram association with 4-hourly teasing, continuous ewe-ram association with 4-hourly teasing, or continuous uncontrolled ewe-ram association provides the most realistic measure of the duration of 'normal' oestrus is open to question. Continuous uncontrolled association between ewes and rams represents the common field situation, yet regular teasing of individual ewes with active rams probably yields a more precise measure of the period for which ewes are physiologically capable of mating, since it eliminates competition between ewes and rams and overcomes the apparent unwillingness of rams to continue to mate with the same ewes for the full duration of their oestrus.

In the first experiment, the linear regressions of incidence, time of onset, and duration of oestrous behaviour on log dose of oestrogen were similar to those already reported (Fletcher \& Lindsay, 1971). Although measurements of oestrous behaviour, and duration of oestrus in particular, varied with method of observation, the slopes of the regression lines were not significantly different. Thus, method of measurement is not important when bio-assaying oestrogens in spayed ewes using parameters of oestrous behaviour as end-points.

\section{AGKNOWLEDGMENTS}

We wish to thank Professor T. J. Robinson for his support of this project, and $\mathrm{Mr} \mathrm{J}$. Ellsmore for field assistance. Financial support from the Australian Wool Board and the Australian Research Grants Committee is gratefully acknowledged.

\section{REFERENCES}

Donovan, B. T. \& Harris, G. W. (1966) Neurohormonal mechanisms in reproduction. In: Marshall's Physiology of Reproduction, Vol. 3, p. 301. Ed. A. S. Parkes. Longmans Green, London.

FLETCHER, I. C. \& LiNDSAY, D. R. (1971) Effect of oestrogen on oestrous behaviour and its variation with season in the ewe. $\mathcal{F}$. Endocr. (in press).

Hulet, G. V., Ercanbrack, S. K., Price, D. A., Blackwell, R. L. \& Wilson, L. O. (1962) Mating behaviour of the ram in the one-sire pen. 7. Anim. Sci. 21, 857.

Lindsay, D. R. (1966) Modification of behavioural oestrus in the ewe by social and hormonal factors. Anim. Behav. 14, 73. 
Lisk, R. D. (1966) Sexual behaviour: hormonal control. Neuroendocrinology, 2, 197.

Parsons, S. D. \& Hunter, G. L. (1967) Effect of the ram on duration of oestrus in the ewe. J. Reprod. Fert. 14, 61.

Pepelko, W. E. \& Clegg, M. T. (1965). Studies of mating behaviour and some factors influencing the sexual response in the male sheep Ovis aries. Anim. Behav. 13, 249.

Robinson, T. J. \& Moore, N. W. (1956) The interaction of oestrogen and progesterone on the vaginal cycle of the ewe. 7. Endocr. 14, 97. 